\title{
Marcus Ehrenpreis in an international context
}

\author{
REPORTS
}

DOI: https://doi.org/10.30752/nj.110938

Report on Inscribing Jewish Community Politics into Space: A Workshop Marking the 70th Anniversary of the Death of Marcus Ehrenpreis (1869-1951), organised by the University of Vienna and University of Gothenburg, 3 June 2021.

This report from the online workshop on 3 June 202 I which took place at the University of Vienna and University of Gothenburg gives an account of the talks and discussions on the role of Rabbi Marcus Ehrenpreis in the Jewish communities of Sofia and Stockholm.

The European Jewish world at the end of the nineteenth and the beginning of the twentieth century was caught up in kaleidoscopic trends. Haskalah and the Reform movement continued to guide many communities, often defined vis-à-vis an imaginary 'Ostjudentum'. A romanticised Orientalism shaped Jewish spaces in the public urban landscape. Meanwhile, Jews from the Balkans, North Africa, the Levant (as former Ottoman subjects), or from Eastern Europe (at least at times affiliated to Orthodox Judaism) were simultaneously excluded from partaking in and/or shaping official Jewish leadership. At the same time, Zionism became a strong Jewish political movement against the backdrop of rising European antisemitism. In this diverse and complex climate, what role did internal discourses and differences play in shaping spaces of 'Jewishness'?
How did Jewish religious leaders relate to the ethnic, religious and political minorities within their communities? In what terms were those minorities constructed? And how did the power relationship become visible in the urban landscape?

These were the questions that the workshop and outreach event 'Inscribing Jewish Community Politics into Space: A Workshop Marking the 7oth Anniversary of the Death of Marcus Ehrenpreis (I869-I95 I)' strove to explore. The workshop was organised by the Department of Art History at the University of Vienna (Austria) in collaboration with the Centre for European Research at the University of Gothenburg (Sweden), and it took place as an online event via Zoom on 3 June 202r. The event was moderated by Dr Mirjam Wilhelm from the Vienna Wiesenthal Institute for Holocaust Studies (Austria) and included two talks by Dr Fani Gargova (University of Vienna) and Dr Maja Hultman (University of Gothenburg). An international cohort of scholars and nonacademics from Bulgaria, Croatia, Austria, Israel, the United Kingdom and Sweden, among others, attended the workshop, providing voices from each country discussed in the workshop. Academic participants came from a wide range of disciplines, such as Jewish studies, Holocaust studies, Irish studies, migration studies, urban studies and art and architectural history. These diverse 
backgrounds were reflected in the multifaceted conversations during the workshop's general discussion.

Mirjam Wilhelm opened the workshop by introducing the main character and protagonist: Marcus Ehrenpreis. As rabbi of Đakovo and Osijek (modern-day Croatia), r 8 96-r 900, chief rabbi of Bulgaria, I900-I4, and chief rabbi of Stockholm (Sweden), I9I4-48, the workshop viewed him as an embodiment of the preconditions, processes and dynamics of the inscription of Jewish community politics into urban space in the nineteenth and twentiseth centuries. Central questions that were raised included whether similarities could be found across disparate European capitals such as Sofia and Stockholm, for instance in the communities' dealing with Jewish diversity in ethnic, ideological and religious outlook, and whether this was articulated through intra-communal conflicts.

Fani Gargova's talk on Ehrenpreis's efforts at 'uniting' the diverse Jewish community in Sofia used the architecture and building process of the new Central Synagogue in the Bulgarian capital, inaugurated in 1909 , to uncover Marcus Ehrenpreis's role in cementing the internal power relations between so-called notables (the established elite), Zionists and other Jewish factions, as well as between the majority Sephardi and minority Ashkenazi communities. While purportedly striving to elevate the status of women and the youth, as well as legitimising the Jewish population's status as equal citizens of the country, Ehrenpreis dismissed local religious or ethnic traditions and characteristics, and pushed for a unified, mainstream, controlled, assimilated and reformed understanding and display of Judaism. With this, he stripped the Jewish community's diversity of the possibility to officially exist and articulate itself.

In her talk on 'Ehrenpreis and Stockholm's Orthodox diversity - spaces of power,

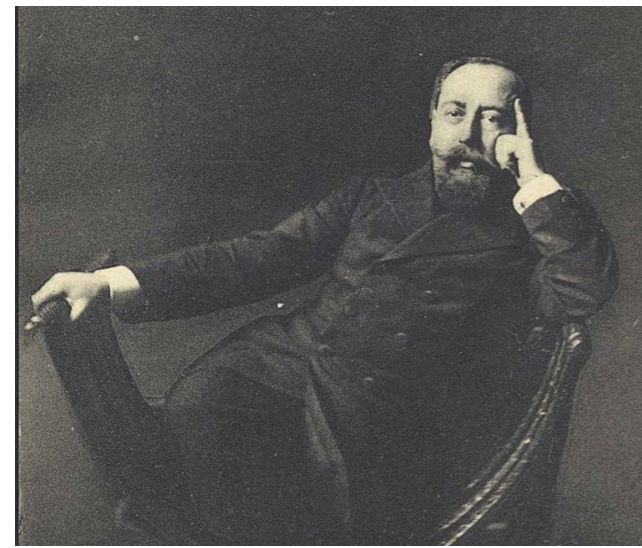

Mordecai Ehrenpreis, 1910. The Schwadron collection of the National Library of Israel.

relations and conflicts', Maja Hultman presented on two religious spaces for Orthodox and/or Eastern European inhabitants of Stockholm and how Marcus Ehrenpreis impacted their disappearance from the Swedish capital's urban topography. As the community's central voice on religious practices and spaces of worship, Ehrenpreis advised against financial support towards the maintenance of smaller minyanim and the mikveh, which was mainly used by Eastern European Orthodox Jews. Designating these spaces as liturgically inconsequential, the rabbi actively worked towards a reformed homogeneity that excluded Stockholm's gendered, religious and ethnic minorities.

Andreas Schein, MA in History from Uppsala University, was scheduled to deliver the third lightning presentation. He was unfortunately unable to attend the workshop. Schein would have underlined Marcus Ehrenpreis's antagonism against Eastern European Jews, which he made public in his sermons, delivered at Stockholm's Great Synagogue. Together, all talks highlighted Rabbi Ehrenpreis's lasting impact on religious, cultural, political, spatial and social aspects of local Jewish life in both Sofia and Stockholm.

The ensuing discussion picked up on many of the themes presented by Fani Gargova 
and Maja Hultman. From the participating audience, we learned that Marcus Ehrenpreis seems to have been a multi-faceted character. Learning the languages of each locale he worked in, he seemed to have aimed at communicating with and understanding the local population, both Jews and non-Jews alike. At the same time, the examples provided in the keynote talks suggested a clear picture of a historical figure with sharp, unbending convictions. The discussion emphasised the continuity of Marcus Ehrenpreis's unsympathetic relationship with ethnic and religious minorities, from Đakovo to Sofia, and finally Stockholm. In spite of that, or rather because of it, the rabbi proved to be a vital force for transformation and change in every community he oversaw. Using language as a strategy to immerse himself in the local society - he made it a goal to learn and communicate in the local languages within a short time - Marcus Ehrenpreis navigated and shaped intellectual and literary discourses, as well as Jewish-non-Jewish relations.

As an outreach event, the workshop also encouraged conversations across the academic/non-academic divide. The discussion on Marcus Ehrenpreis's relation to gender, and the role of his wife Esther Ehrenpreis more specifically - who had hitherto remained in his shadow - benefited greatly from the workshop's open character. Revealing the importance of contemporary witnesses and the power of oral history, two participants recounted their childhood memories of the couple, painting a powerful and personal picture of Marcus Ehrenpreis's patriarchal handling of his wife, but also of Esther Ehrenpreis's strong presence. Since not much archival material related to her exists - participants told of personal diaries that are known to have existed but are today lost - the workshop exemplified how academia can draw on knowledge from the non-academic sphere, such as personal reflections and stories, to extend scholarly understanding of persons and places, and their role in society at large. At the same time, the new academic research presented during the event, hinting at Marcus Ehrenpreis's vital role in community politics in the Balkans and the Scandinavian countries, had an impact beyond scholarly debate on the wider interested public.

In conclusion, Marcus Ehrenpreis turned out to be a worthwhile entry point for discussing European Jewish communal politics and internal community conflicts in a transEuropean, interdisciplinary and comparative perspective. As a religious and cultural leader, his actions shaped the dialectics between Reform and Orthodox Judaism, between Central and Western European hegemony over 'peripheral' communities, and between the frictions of ethnic, religious and political minorities and their relationships with the community leadership. His role in the Jewish communities in Sofia and Stockholm underlines his continuous disregard of diverse understandings of Judaism, and his actions derived from this disregard. Although motivated by a strong belief in the empowerment of local Jewry, Marcus Ehrenpreis's established convictions and strategies, which did not vacillate though time, space or environment, nevertheless revealed the dialectics of particularisms and unification which shaped the contemporary map of Jewish Europe.

MAJA HULTMAN

Post-doctoral researcher at the Centre for European Research and the Department of Historical Studies at the University of Gothenburg

FANI GARGOVA

Assistant professor in Art History at the University of Vienna 